\title{
Síndrome de Melkersson Rosenthal: reporte de un caso y revisión de la literatura
}

\author{
Melkersson-Rosenthal syndrome: case report and literature review
}

\author{
R. Cosmelli Maturana', R. Bravo Ahumada², L. Cordova Jara'
}

\begin{abstract}
Resumen: El Síndrome de Melkersson Rosenthal se describe como la asociación de edema labial (queilitis granulomatosa de Miescher) y/o facial recurrente, parálisis facial recidivante y lengua fisurada. El edema labial recurrente se presenta en uno o ambos labios, el cual puede llegar a ser persistente. Cuando se presenta en forma aislada se considera como una forma monosintomatica de este síndrome. El objetivo de esta revisión es mostrar el seguimiento de un caso clínico atendido en nuestro servicio con el diagnóstico síndrome de Melkersson Rosenthal que presenta una gran queilitis granulomatosa asociada a lengua fisurada, cuyo tratamiento consistió en la infiltración de corticoides intralesionales y una posterior queiloplastía.
\end{abstract}

Palabras clave: Síndrome de Melkersson Rosenthal; Queilitis granulomatosa; Queiloplastía.

Recibido: 31.03 .2008

Aceptado: 16.06 .2008

\begin{abstract}
Melkersson-Rosenthal syndrome is described as the association of recurrent lip edema (Miescher's cheilitis granulomatosa) and/or facial edema, recurrent facial paralysis, and plicated tongue. Recurrent edema occurs in one or both lips, and can be persistent. When lip edema alone occurs, the case is considered a monosymptomatic form of this syndrome. The aim of this review was to discuss the follow-up of a patient seen in our department with the diagnosis of Melkersson-Rosenthal syndrome who presented intense cheilitis granulomatosa associated with plicated tongue. The patient was treated with infiltration of intralesional corticoids and later cheiloplasty.
\end{abstract}

Key words: Melkersson-Rosenthal syndrome; Cheilitis granulomatosa; cheiloplasty.

1 Cirujano Dentista. Meritante Equipo de Cirugía Maxilofacial.

2 Cirujano Maxilofacial. Equipo de Cirugía Maxilofacial.

Complejo Hospitalario San José, Santiago de Chile, Chile

\section{Correspondencia:}

Dr. Rodrigo Cosmelli Maturana.

Complejo Hospitalario San José,

Santiago-Chile

rcosmelli@gmail.com 


\section{Introducción}

El síndrome de Melkersson Rosenthal (SMR) es una patología rara y de origen desconocido, caracterizado por tres signos clínicos, inflamación labial y/o facial recurrente, lengua fisurada y parálisis facial. 1-3 $^{-3}$ Siendo frecuentes las exacerbaciones de la enfermedad, así como su recidiva. La tumefacción orofacial se caracteriza por labios inflamados y fisurados y de una coloración rojo parduzca.

Sin embargo, la aparición de la triada clásica del SMR es infrecuente, pues aparece aproximadamente entre el 25$40 \%$ de los casos, ${ }^{2}$ presentando generalmente formas oligosintomáticas o monosintomáticas de la enfermedad, siendo la queilitis granulomatosa, la forma monosintomática más común. 2,4 La queilitis granulomatosa (QG) fue descrita por Miescher en 1945, ${ }^{4}$ caracterizada por la aparición de una tumefacción labial recurrente que responde a una reacción inespecífica granulomatosa en uno o ambos labios, el cual puede llegar a ser persistente. Regularmente se produce aumento de tamaño del labio inferior, uniformemente tumefacto, que puede asociarse con otras tumefacciones intraorales, especialmente de paladar y suelo de la boca. Además del problema estético, el labio agrandado y desfigurado suele producir dificultades al paciente al comer, beber y hablar. ${ }^{3,5}$

Completa el diagnóstico de SMR el hallazgo histológico de granulomas tipo sarcoide no caseificantes, sin embargo su aparición no es constante, pero su ausencia no excluye el diagnóstico de SMR si están presentes otros signos.

Las manifestaciones clínicas de este síndrome se manifiestan en el $50 \%$ de los casos después de los 20 años de edad 6,7 y una predilección por las mujeres. 2,8

El tratamiento de esta patología es controversial, ya que no está completamente dilucidado su mecanismo etiopatogénico. Se han probado distintos tratamientos con resultados variables, desde el uso de corticoides sistémicos e intralesionales solos o combinados con otros fármacos para aumentar su efectividad y en casos residuales se ha recurrido a un tratamiento quirúrgico, con algunos reportes de recidiva.

El presente trabajo tiene como objetivo presentar el seguimiento de un caso clínico atendido en nuestro servicio con el diagnóstico SMR que presenta una gran QG asociada a lengua fisurada, cuyo tratamiento consistió en la infiltración de corticoides intralesionales y una posterior queiloplastía.

\section{Caso Clínico}

Se presenta una paciente de género femenino de 24 años de edad que consulta al Servicio de Cirugía Maxilofacial del Compleform, with cheilitis granulomatosa being the most common monosymptomatic form. ${ }^{2,4}$ Cheilitis granulomatosa (CG) was described by Miescher in 1945.4 It is characterized by the appearance of recurrent labial swelling produced by a nonspecific granulomatous reaction in one or both lips, which may eventually become persistent. The size of the lower lip generally increases, consisting of uniform swelling that may be associated with other intraoral swelling, especially of the palate and mouth floor. In addition to the esthetic problem, the enlarged and disfigured lip usually gives the patient difficulties when eating, drinking, and speaking.3,5

The diagnosis of MRS is completed by the histologic finding of noncaseifying, sarcoid type granulomas, although their presence is not constant. The absence of this symptom, however, does not exclude the diagnosis of MRS if other signs are present.

The clinical manifestations of this syndrome are manifested in $50 \%$ of cases after the age of 20 years 6,7 and MRS shows a predilection for women. 2,8

The treatment of this pathology is controversial because its etiopathogenic mechanism has not been fully explained. Different treatments have been tried with variable results. Therapeutic options range from the systemic and intralesional use of corticoids, alone, or combined with other drugs to increase their effectiveness. Surgical treatment has been resorted to in residual cases and there have been reports of recurrence.

The current study presents a clinical case of a woman seen in our department with a diagnosis of MRS and intense CG associated with plicated tongue. Her treatment consisted of intralesional infiltration of corticoids and later cheiloplasty. 
jo Hospitalario San José en octubre de 2006, derivado del Servicio de Dermatología del mismo centro con diagnóstico de SMR por presentar aumento de volumen del labio inferior que no ha presentado respuesta al tratamiento con corticoides intralesionales y orales.

La paciente relata que este aumento de volumen en el labio inferior data del año 2004, el cual fue biopsiado el mismo año siendo diagnosticado histopatológicamente como una QG asociada a un SMR. El tratamiento inicial consistió en infiltraciones intralesionales realizadas en el servicio de dermatología con betametasona $4 \mathrm{mg}$ y toma de prednisona $0,5 \mathrm{mg}$ sin resultados positivos.

En su anamnesis relata antecedentes mórbidos de epilepsia en tratamiento, retraso mental leve, hipotiroidismo, resistencia a la insulina y alergia al yodo. Los fármacos que utiliza en forma habitual son Levotiroxina 100 mg 1 comp/día, Carbamazepina 200 mg 1,5 comp/día, Metformina $850 \mathrm{mg} 1 \mathrm{comp} /$ día.

En su examen físico se observa un gran aumento de volumen del labio inferior el cual está evertido (Figs. 1 y 2), asociada a una lengua depapilada y presencia de surcos transversales en dorso lingual compatible con lengua fisurada así como una discreta macroglosia (Fig. 3).

El tratamiento consistió en 3 infiltraciones intralesionales en el labio inferior de $1 \mathrm{ml}$ de Kenacort ${ }^{\circledR}$-A 40 mg (Triamcinolona acetónido) diluida en $1 \mathrm{ml}$ de lidocaína al $2 \%$ con el objetivo de controlar el dolor post infiltración, con intervalos de una semana. Se controló a la paciente durante tres meses donde se evidencio una marcada reducción del tamaño del labio inferior pero sin lograr todavía un tamaño estético, por lo tanto se realizó una cuarta infiltración sin observarse mejoras (Figs. 4 y 5). Luego se programo una queiloplastía de reducción del labio inferior bajo anestesia general para

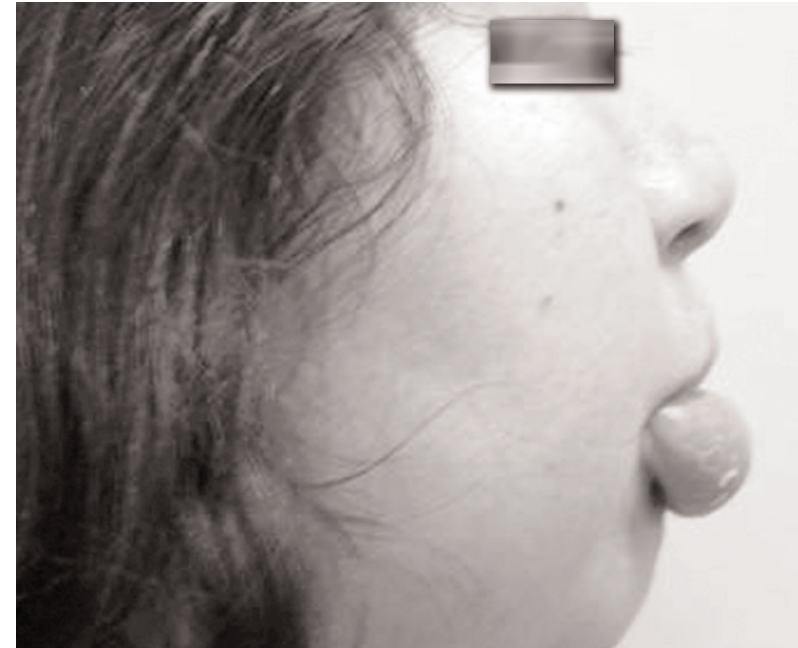

Figura 2. Imagen lateral.

Figure 2. Lateral view.

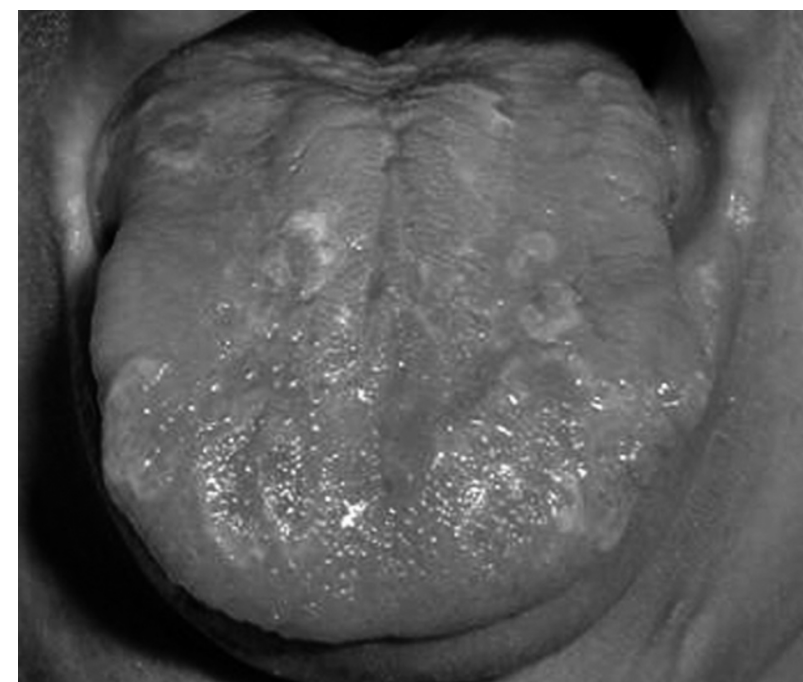

Figura 3. Aspecto de la lengua.

Figure 3. Aspect of the thonge.

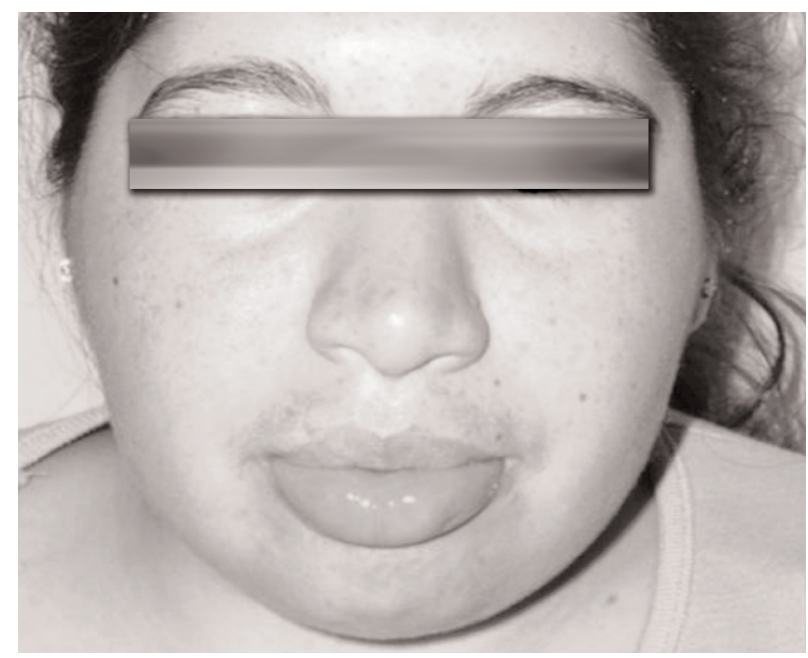

Figura 4. Aspecto tras las primeras infiltraciones Figure 4. Aspect after the inital infiltrations.

\section{Clinical case}

A 24-year-old woman was seen in the Maxillofacial Surgery Department of San José Hospital Complex in October 2006, referred from the Dermatology Department of the same center with a diagnosis of MRS. Her increased lower lip volume had not responded to treatment with intralesional and oral corticoids.

The patient stated that her lower lip began to increase in volume in 2004. A biopsy performed that year yielded a histopathologic diagnosis of CG associated with MRS. The initial treatment consisted of intralesional infiltration performed in the dermatology department with betamethasone $4 \mathrm{mg}$ and prednisone $0.5 \mathrm{mg}$, which failed to produce satisfactory results.

In the interview, the patient related a medical history of epilepsy, which was under treatment, mild mental retardation, hypothyroidism, insulin resistance, and iodine allergy. She regularly took levothyroxine $100 \mathrm{mg}, 1$ tablet/day, carbamazepine 200 mg, 1.5 tablet/day, metformin $850 \mathrm{mg}, 1$ tablet/day.

The physical examination disclosed a large increase in the volume of the lower lip and lip eversion (Figs. 1 and 2), which were associated with depapillation and transversal furrows on the dorsal tongue consistent with plicated tongue, as well as discrete macroglossia (Fig. 3).

Treatment consisted of 3 intralesional infiltrations in the lower lip of $1 \mathrm{ml}$ Kenacort ${ }^{\circledR}$ - $440 \mathrm{mg}$ (triamcinolone acetonide) diluted in $1 \mathrm{ml}$ of lidocaine $2 \%$ to control postinfiltration pain, which were administered at one-week intervals. The patient was followed up for three months, during which the size of the lower lip decrease markedly, but without achieving an esthetically acceptable result. 
mejorar la estética labial de la paciente, con buenos resultados que fueron controlados al mes post operatorio (Figs. 6 y 7).

\section{Discusión}

EI SMR es una enfermedad constituida por una triada clínica compuesta por edema facial o labial recurrente, parálisis facial recidivante y lengua fisurada, siendo la QG la forma monosintomática más común. ${ }^{1}$

La etiología del SMR es desconocida, aunque en la actualidad se barajan tres posibles orígenes de la enfermedad: el infeccioso, ${ }^{9}$ el inmunológico desencadenado por alergia o intolerancia a algunos alimentos, ${ }^{9}$ y un posible origen genético. ${ }^{10,11}$ Por esta razón los tratamientos también han sido diversos, se han usado numerosos fármacos tanto locales como sistémicos: antibióticos sistémicos, salazosulfapiridina, radioterapia, corticoides tópicos, intralesionales y sistémicos, fármacos antileprosos, asociados, en muchos casos a una queiloplastía labial para alcanzar mejores resultados, 12, 13 sin embargo, los resultados no siempre han sido satisfactorios.

El uso de esteroides ha demostrado buenos resultados en la mejoría de la mayoría de estos pacientes. ${ }^{14}$ Para este caso se aplico Acetónido de Triamcinolona, que es un corticoesteroide dotado de potente y duradera acción antiinflamatoria, hormonal y metabólica. A pesar de que la Triamcinolona misma es aproximadamente 1 a 2 veces más potente que la prednisona en modelos animales de inflamación, el derivado denominado Acetónido de Triamcinolona es más potente aún, siendo aproximadamente, 8 veces más potente que la Prednisona. ${ }^{15}$ Dentro de las precauciones que se tienen presentes con este fármaco, tienen que ver con su prolongada duración y potencia, describiéndose supresión adrenal total con la simple infiltración intramuscular de entre 60 a 100 mg de acetónido de triamcinolona entre las 24 a 48 horas post infiltración, función que se recupera en forma progresiva a los 30 a 40 días. Por esta razón es que se instauró una tera-

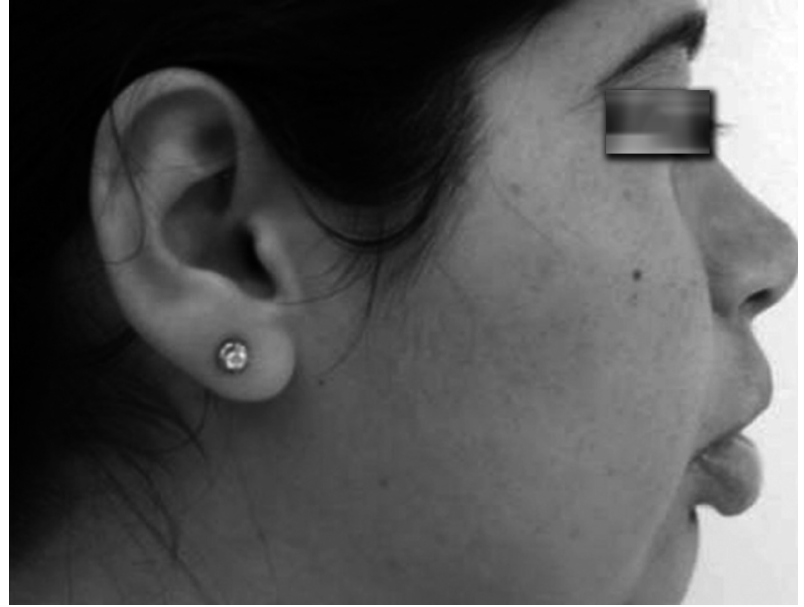

Figura 5. Aspecto antes de la cirugía. Figure 5. Aspect before surgery.

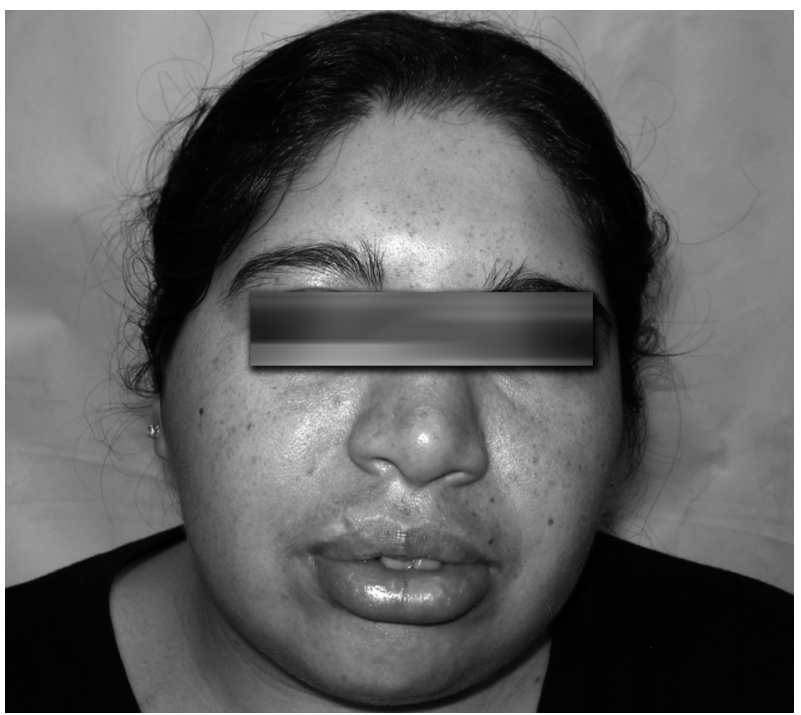

Figura 6. Imagen tras la queiloplastia. Figure 6. Image after cheyloplasty.

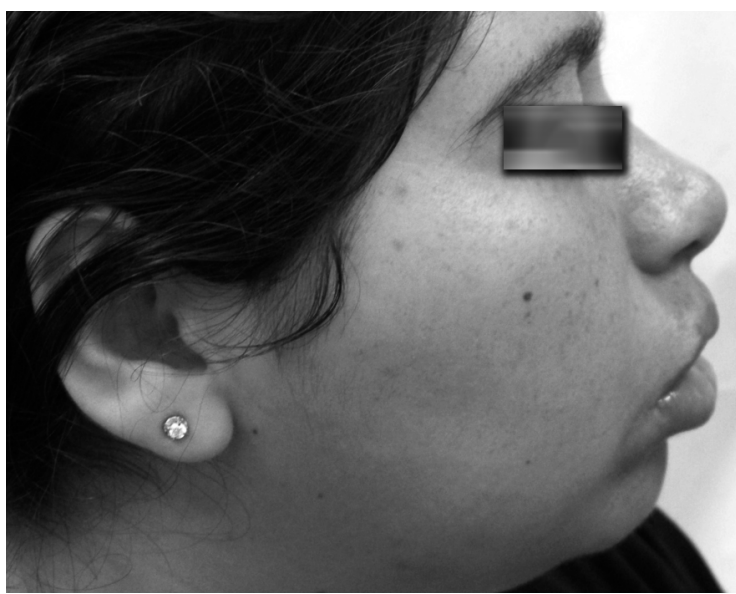

Figura 7. Vista lateral tras la cirugía. Figure 7. Lateral view after surgery.
A fourth infiltration was given but no improvement was observed (Figs. 4 and 5). A lower-lip-reduction cheiloplasty was performed under general anesthesia to improve the appearance of the patient's lip. The results were good one month after surgery (Figs. 6 and 7).

\section{Discussion}

MRS is a disease constituted by a clinical triad consisting of facial or labial edema, recurrent facial paralysis, and plicated tongue. CG is the most common monosymptomatic form of MRS. ${ }^{1}$

The etiology of MRS is not known, but three possible origins of the disease are being discussed: infection, ${ }^{9}$ an immunologic reaction triggered by allergy or food intolerance, ${ }^{9}$ and a possible genetic component. ${ }^{10,11}$ Given the lack of a clear etiology, the treatments have been diverse and numerous topical and systemic drugs have been used: systemic antibiotics, salazosulfapyridine, irradiation, topical, intralesional and systemic corticoids, and antileprosy drugs. Cheiloplasty often is associated to enhance results. ${ }^{12,13}$ Nevertheless, the results have not always been satisfactory.

The use of steroids has produced good results in improving most of these patients. ${ }^{14}$ We gave this patient triamcinolone acetonide, a corticoid with a powerful and prolonged anti-inflammatory, hormonal, and metabolic effect. Although triamcinolone is approximately 1 to 2 times stronger than prednisone in animal models of inflammation, the derivative known as 
pia de infiltración máxima de 40 mg de acetónido de triamcinolona, una vez a la semana por tres semanas. Los resultados fueron aceptables pero no óptimos por lo que se realizó una nueva infiltración intralesional a los tres meses con el mismo fármaco, sin embargo no se observó una mayor reducción labial por lo que se planificó y realizó una queiloplastía de reducción.

Es importante en el tratamiento de estos pacientes un trabajo multidisciplinario, ya que no existe una terapia estandarizada, debido a que no existe claridad en la literatura respecto a los mecanismos etiopatogénicos, con reportes de casos y series de casos con tratamientos con resultados variables.

Los pacientes que sufren un SMR probablemente deban enfrentarse a la recurrencia de sus síntomas durante una gran parte de sus vidas, ya que las alternativas de tratamiento no suelen ser definitivas.

\section{Bibliografía}

1. Stein SL, Mancini AJ. Melkersson-Rosenthal syndrome in childhood: Successful management with combination steroid and minocycline therapy. J Am Acad Dermatol 1999;41:746-8.

2. Zimmer WM, Rogers RS, Reeve CM, Sheridan PJ. Orofacial manifestations of Melkersson-Rosenthal syndrome. A study of 42 patients and review of 220 cases from literature. Oral Surg Oral Med Oral Pathol 1992;74:610-9.

3. Sapp JP, Eversole LR, Wysocki GP. Patología Oral y Maxilofacial Contemporánea. $2^{a}$ ed. Mosby, 2005 Edición en Español. Elsevier España, S.A.

4. Miescher G. Ubre essentielle granulomatöse macrokelie (cheilitis granulomatosa). Dermatológica 1945;91:57-85.

5. Camacho-Alonso F, Bermejo-Fenoll A, López-Jornet P. Queilitis granulomatosa de Miescher. Presentación de cinco casos. Med Oral Patol Oral Cir Bucal 2004; 9:425-9.

6. Alexander RW, James RB. Melkersson-Rosenthal syndrome: review of literature and report of case. J Oral Surg 1972;30:599-604.

7. Worsaae $\mathrm{N}, \mathrm{y}$ cols. Melkersson-Rosenthal syndrome and cheilitis granulomatosa. A clinicopathological study of thirty-three patients with special reference to their oral lesions. Oral Surg Oral Med Oral Patho 1982;154:404.

8. Greene RM, Rogers RS III: Melkersson-Rosenthal syndrome: A review of 36 patients. J Am Acad Dermatol 1989;21:1263.

9. Ang KL, Jones NS. Melkersson-Rosenthal Syndrome. J Laryngol Otol 2002;116:3868.

10. Gerressen M, et al. Melkersson-Rosenthal syndrome: case report of a 30-Year Misdiagnosis. J Oral Maxillofac Surg 2005;63:1035-9.

11. Shapiro M, Peters S, Spinelly HM. Melkersson-Rosenthal Syndrome in the periocular area: A Review of the literature and Case Report. Ann Plast Surg 2003; 50:644-8.

12. Ellitsgaard N, Andersson AP, Worsaae N, Medgysei S. Long-term results after surgical reduction cheiloplasty in patients with Melkersson-Rosenthal syndrome and cheilitis granulomatosa. Ann Plast Surg 1993;31:413-20.

13. Cederna PS, y cols. Melkersson- Rosenthal Síndrome: Reduction Cheiloplasty Utilizing a Transmodiolar Labial Suspension Suture. Plastic Surgery. Aesthetic Plastic Surg 1998;22:102-5.

14. El-Hakim M, Chauvin P. Orofacial Granulomatosis Presenting as Persistent Lip Swelling: Review of 6 New Cases. J Oral Maxillofac Surg 2004;62:1114-7.

15. Hernecki J, Sararols L. Triamcinolona acetónido en el tratamiento del edema macular diabético. Annals d'Oftalmologia 2004;1:71-6. triamcinolone acetonide is even stronger, being approximately 8 times more potent than prednisone. 15 The necessary precautions to be considered with this drug include those related with its prolonged duration and potency. Total adrenal suppression has been reported with a single intramuscular infiltration of 60 to $100 \mathrm{mg}$ of triamcinolone acetonide, which appears 24 to 48 hours after infiltration; adrenal function recovers gradually over 30 to 40 days. Consequently, we started therapy with a maximum infiltration of $40 \mathrm{mg}$ of triamcinolone acetonide, once weekly, for three weeks. The results were acceptable, but not optimal, so a new intralesional infiltration of the same drug was made at three months. However, further labial reduction was not achieved and a reduction cheiloplasty was performed.

Multidisciplinary cooperation is important in the management of these patients because no standardized therapy exists. Consensus is still lacking in the literature on the etiopathogenic mechanisms involved. Cases and series of cases with a variety of treatments and a range of results have been reported.

Patients with MRS probably will experience a recurrence of symptoms in the course of their lives because the therapeutic alternatives usually do not provide any definitive solution. 